\title{
Contributing Stressor towards Self Adjustment Among Foreign Students in Public University
}

\section{Abdul Rashid Abdul Aziz}

To Link this Article: http://dx.doi.org/10.6007/IJARBSS/v11-i10/11463

DOI:10.6007/IJARBSS/v11-i10/11463

Received: 02 August 2021, Revised: 25 August 2021, Accepted: 17 September 2021

Published Online: 11 October 2021

In-Text Citation: (Aziz, 2021)

To Cite this Article: Aziz, A. R. A. (2021). Contributing Stressor towards Self Adjustment Among Foreign Students in Public University. International Journal of Academic Research in Business and Social Sciences, 11(10), $1038-1052$.

\section{Copyright: @ 2021 The Author(s)}

Published by Human Resource Management Academic Research Society (www.hrmars.com)

This article is published under the Creative Commons Attribution (CC BY 4.0) license. Anyone may reproduce, distribute, translate and create derivative works of this article (for both commercial and non-commercial purposes), subject to full attribution to the original publication and authors. The full terms of this license may be seen at: http://creativecommons.org/licences/by/4.0/legalcode

Vol. 11, No. 10, 2021, Pg. $1038-1052$

Full Terms \& Conditions of access and use can be found at http://hrmars.com/index.php/pages/detail/publication-ethics 


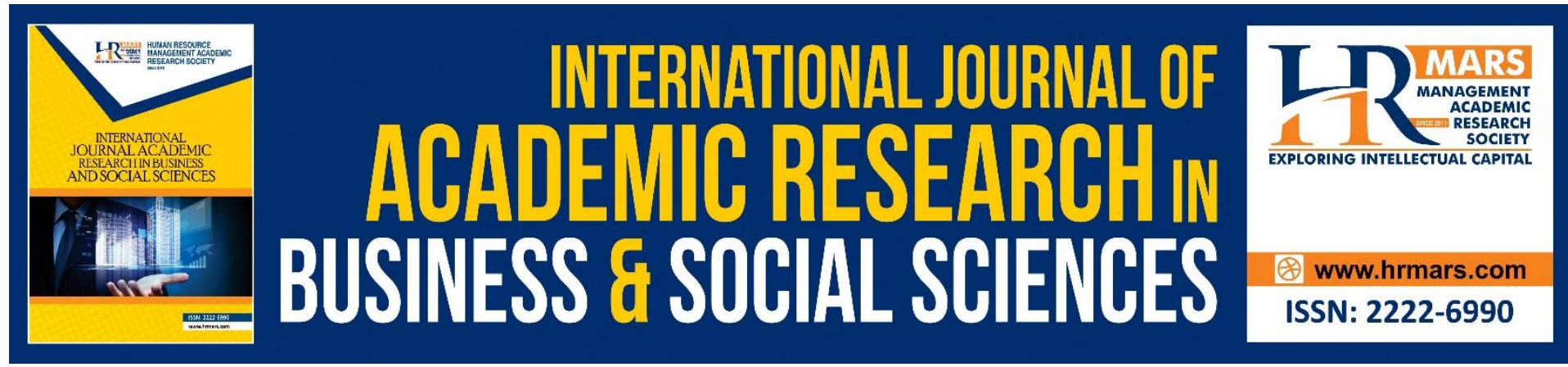

\title{
Contributing Stressor towards Self Adjustment Among Foreign Students in Public University
}

\author{
Abdul Rashid Abdul Aziz \\ Faculty of Leadership and Management, Universiti Sains Islam Malaysia \\ Negeri Sembilan, Malaysia
}

\begin{abstract}
The number of foreign students enrolling institutions of higher learning in Malaysia is increasing in trend. Despite of that, studies related to the problems faced by them during the learning period in Malaysia are still lacking and limited. Thus, this paper was conducted to explore the contributing stressor towards self-adjustment among foreign students who pursuing their higher education in Malaysia. It is a qualitative study where semi-structured interviews were conducted in depth among 5 foreign postgraduates' students in Malaysia. The data was then analyzed using thematic analysis. Five themes and ten sub-themes emerged from the interviews, including academic stressor (teaching and learning approaches with English language, and experiences with student support services), financial stressor (scholarship endorsement/ fellowship and financial management), psychological stressor (loneliness and homesickness), language stressor (language and communication barrier and lack of confidence in verbal skills) and sociocultural stressor (cross-cultural friendships, food incompatibilities). These stressors will further determine the capability of foreign students in their self-adjustment which leads to the student's well-being. This study can be a new platform and source of reference, especially for higher educational institutions to ensure that the welfare of each foreign student is maintained and making Malaysian higher education institutions as one of the foremost institutions in the world.
\end{abstract}

Keywords: Contributing Stressor, Self-Adjustment, Foreign Student, International, Education

\section{Introduction}

The system enforced in Malaysian higher learning institution has made significant increment in student enrolment, risen in global recognition on key dimensions including research publications, patents, and institutional quality, as well as becoming the uppermost destination for foreign students for over the last ten years (Malaysia Education Blueprint 2015-2025). Malaysia has become the destination of choice for foreign students to further their education (Cheng et al., 2013). Higher education in Malaysia has grown rapidly and it is emulating United States of America which is well known as foreign student destinations for education (Choudaha \& Chang, 2012; Lam et al., 2017). Based on the Higher Education Statistics 2018 produced by Ministry of Education Malaysia (MOHE), about 170,898 foreign students was enrolled in institutes of higher education in Malaysia. Most of these students have arrived from Bangladesh, China, Nigeria, Indonesia, Yemen, Pakistan, Iraq, Libya, Iran 
and India. The number has grown from 150,000 foreign students enrolled in 2017 (Annuar, 2017) and the figure is anticipated to increase to 200,000 by this year (MOHE, 2011). Besides, the increment was in line with the government's mission in making Malaysia as a center of excellence in higher education in the Southeast region.

This significant rise has led to an increase in issues related to students' stress and selfadjustment while studying in Malaysian universities. Adjusting to life in university or college can be stressful for any students but for foreign students, this stress is often multiplied (Nilsson et al., 2008). This is contributed by the fact that they need to adjust and cope with various challenging tasks related to acculturation. According to Sarafino (2012), stress arises when individuals perceive an incongruity between the physical or psychological demands of a situation and the resources of his or her biological, psychological or social systems. Previous scholar revealed a lot of stressors which foreign students have to face throughout their academic years including academic pressure, language obstacles, nostalgia, and damage of social backup, reduced self-esteem, perceived discrimination, absence of coping strategies, different living condition and limited financial (Poyrazli \& Grahame, 2007; Mori, 2000; Safary \& Nadine, 2012).

In Malaysia, recent study conducted by Shafaei \& Razak (2016) have identified several key indicators of adjustment that can be used to explain the psychological and sociocultural adjustment challenges by many foreign postgraduate students which includes cultural differences, academic and life stress, financial problems, felt prejudice and bias, cross-cultural self-efficacy, social support, and interaction with Malaysians. Meanwhile, Hsiao-ping et al., (2015) mentioned that foreign students have to deal with people, society, school, psychological status, and behavioral changes in order to adapt to the new environment. Foreign students come with their different sociocultural backgrounds. Such diversity demands that foreign students to fit into the new environment and lifestyle of their host country (Ahrari et al., 2019). Poor self-adjustment towards stress may leads to social, psychological and academic implications (Bailey \& Phillips, 2016).

Deitchman (2014) stated that many services developed at many universities for foreign students are merely on the basis of assumptions about the needs of foreign students rather than on a structured assessment of their needs. Research related to foreign student adjustment is very important and most needed in raising awareness of the issues faced by foreign students and the stressors emerged in adjusting to a host country. Therefore, exploring the potential stressor and understanding the adjustment process among foreign students is vital and critical in order to ensure all of foreign students attain the best possible learning and living experiences throughout their stay in Malaysia.

\section{Literature Review}

Malaysia offers a world-class ranked education where many universities in this country have been listed as the best universities in the world. One of the indicators in becoming a renowned university is measured from the aspect of foreign students enrolling in such institutions. Foreign students also act as ambassadors for Malaysia when they return to their country of origin (Annuar, 2017). In fact, through the Ministry of Education's Interim Strategic Plan 2011-2020 targeted Malaysia as a global education hub which comparable to other developed countries (Ministry of Education, 2012). Therefore, enrolment of these 
foreign students needs to be monitored closely to ensure their level of well-being in adapting to the social and university environment is well preserved. This is because, the university is an environment which requires students to balance their roles and tasks that need to be performed (Mustafa et al., 2009).

Certainly, stress is unavoidable in every human being. Indeed, every change in the phase of human life also requires a process of adaptation which exerts stress and implication on individual's psychological well-being. In the discipline of psychology, stress occurs and functions from an emotional, cognitive and intrapersonal aspects (Aris, 2014). Stress can also be referred to as a physical response to changes that require mental, physical and emotional adjustment (Angela, 2019), and attitudes towards a situation that is considered threatening (Othman and Sipon, 2012). When individuals leave their country to continue their studies, they are certainly will facing with the issue of adapting to new norms, cycles, cultural customs and languages. In fact, the challenges with academic that has been go through by the students further put them in more stressful condition (Jean \& Kaye, 2016).

Adjustment generally means the act or process of adjusting to oneself or one's environment (Merriam-Webster, 2020). A study of Malaysian students studying abroad through data analysis from interview found that there are seven forms of acculturation stress experienced by the subjects in the perspective of cultural shock which include negative perception of society in new culture, discrimination, education system, language barriers, homesickness and loneliness. (Salleh and Hussin, 2017). In addition, a survey conducted by Suseela \& Poovaikarasi (2011) in identifying the adjustment problems faced by foreign students in Malaysia found that the factors which contribute to the problems following in order based on the highest mean value are academic adjustment (mean value 88.92), followed by religion adjustment (mean value 69.72), personal adjustment (mean value 68.50), social adjustment (mean value 66.28), financial adjustment (mean value 38.19 ) and finally language adjustment (mean value 21.34).

The transition of student migration from one country to another has many consequences for themselves and among the issues that is often facing by foreign students are adaptation in academic, social, cultural and psychological aspects which leads to homesickness, depression and anxiety (Jean \& Kaye, 2016). This factor is seen in more depth in the study of Wu et al., (2015) who conducted a qualitative study using interviews approach towards foreign students found that the subjects faced issues such as learning challenges, social isolation and socio-cultural adaptation. While Russell et al (2010) found that almost 41 percent of foreign students in their study faced substantial stress in relation to issues such as homesickness, cultural shock, or perceived discrimination. In contrary, qualitative studies through interview and observation methods conducted by Gebhard (2012) on the experience of the adaptation process of foreign students revealed a different finding. This is because, the results of the study found that foreign students face academic issues, social interaction and emotional control (handling emotions) in their lives and they will use behaviour coping skills in dealing with this adjustment issue.

\section{Methodology}

This research opted a qualitative research method. The respondent was chose using purposive sampling method. A semi-structured, in-depth face to face interviews were 
conducted with 5 postgraduates' foreign students from one of the public universities in Peninsular Malaysia. Table 1 lists the demographics of the 5 students that were selected. The foreign students were interviewed by research team to obtain a complete and holistic view based on the context of the study and research questions. Interview sessions were held at the researcher's office or participants' place if participants did not have transportation. Each interview lasted for about 60 minutes. Interviews were audiotaped or videotaped. The collected data were manually analyzed using thematic analysis.

Majority of the informants have a length of residence of 6 month and below. The selection was made based on the fact that most of the foreign students need time for them to adjust themselves in their new environment. This is further supported by study done by Trice (2004); Mittal \& Wieling's (2006); de Araujo (2011) which found that length of stay in the host country is one of the significant factors relating to adjustment. In other study, Sodowsky and Plake (1992), revealed that foreign who lived for more than six years in the U.S. were significantly more adjusted than those who had lived three to five years and zero to two years. Meanwhile, Diagnostic and Statistical Manual of Mental Disorder V, DSM-V (2018) defined adjustment disorder as the development of emotional or behavioral symptoms in response to an identifiable stressor(s) occurring within 3 months of the onset of the stressor(s). In details, DSM-V further detailed the classification where acute disorder occurs for less than 6 month and chronic disorder occur for more than 6 months.

Table 1: Demographics of The Participants

\begin{tabular}{|c|c|c|c|c|c|}
\hline $\begin{array}{c}\text { Pseudo } \\
\text { names }\end{array}$ & $\begin{array}{c}\text { Length of } \\
\text { residence } \\
\text { (years) }\end{array}$ & Gender & Age & $\begin{array}{c}\text { Country of } \\
\text { origin }\end{array}$ & $\begin{array}{c}\text { First } \\
\text { language }\end{array}$ \\
\hline Informant 1 & 6 months & Female & 24 & South Korea & Korean \\
\hline Informant 2 & 9 months & Male & 29 & Iran & Persian \\
\hline Informant 3 & 2 months & Female & 25 & Iran & Persian \\
\hline Informant 4 & 2 months & Male & 27 & Bangladesh & Bengali \\
\hline Informant 5 & 1 year & Male & 26 & Turkey & Turkish \\
\hline
\end{tabular}

\section{Results and Analysis}

Analysis of the data revealed 5 major themes capturing the involved stressor of participant's self-adjustment in this study. The themes were classified as academic stressor, financial stressor, psychological stressor, language stressor and sociocultural stressor. Each of the themes are further elaborated in details through the identification of sub-themes, as shown in Table 2. 
Table 2: Summary of Themes

\begin{tabular}{|c|c|c|}
\hline Main theme & Sub-themes 1 & Sub-themes 2 \\
\hline Academic stressor & $\begin{array}{l}\text { Teaching and } \\
\text { learning } \\
\text { approaches } \\
\text { with English } \\
\text { language }\end{array}$ & $\begin{array}{c}\text { Experiences } \\
\text { with student } \\
\text { support services }\end{array}$ \\
\hline Financial stressor & $\begin{array}{l}\text { Scholarship } \\
\text { endorsement/ } \\
\text { fellowship }\end{array}$ & $\begin{array}{c}\text { Financial } \\
\text { management }\end{array}$ \\
\hline Psychological stressor & Loneliness & Homesickness \\
\hline Language stressor & $\begin{array}{c}\text { language and } \\
\text { communication } \\
\text { barrier }\end{array}$ & $\begin{array}{c}\text { Lack of } \\
\text { confidence in } \\
\text { verbal skills } \\
\end{array}$ \\
\hline Sociocultural stressor & $\begin{array}{c}\text { Cross-cultural } \\
\text { friendships }\end{array}$ & $\begin{array}{c}\text { Food } \\
\text { incompatibilities }\end{array}$ \\
\hline
\end{tabular}

\section{Academic Stressor}

Academic stressor was marked by the experiences and challenges related to the education process in Malaysian universities. It is among important aspects which need to be looked in details as failure to cater with academic stressor will interrupt with student's academic performance and general well-being.

\section{Sub-Theme 1 (Teaching and learning approaches with English language)}

Language plays an important predictor in participants' academic stressor. Many participants indicated that teaching and learning approaches with English is a main stressor for them although they have studied English for several years in their countries. Majority of them have a low proficiency in English.

Excerpt 1 (Informant 3)

"My English proficiency is not very good. Most of the time, I cannot understand the lecture. The reading is very difficult. I need extra time to go through every of reading materials and completed tasks given by lecturer. Sometimes, I was left out when the lecturer assigned us in group discussion."

Excerpt 2 (Informant 4)

"I'm so stress. I need to polish my English. It's hard for me to communicate with my supervisor for a certain task given."

\section{Sub-Theme 2 (Experiences with student support services)}

Students support services are needed in dealing with academic stressor. In this study, majority of the participants revealed bad experiences with student support services. They did not aware what are the facilities available surrounding them and they are not comfortable with the services.

Excerpt 3 (Informant 1)

"A lot of time, I don't know where I should go to whenever I encountered with the problem." 


\section{Financial Stressor}

For most of the participants, financial constraints are the main contributing stressor in adjusting live in Malaysia. A stable financial status is very crucial in every foreign student as they need the money to spend on their educational fees, teaching material, activities related to academic completeness, food, place to stay, logistic reasons and a lot more.

\section{Sub-Theme 1 (Scholarship endorsement/fellowship)}

Most of the student revealed that financial status is one of the stressors in their student's life. This is because most of them failed to get scholarship endorsement from their own country and they need to support all the spend needed for education and living in Malaysia by themselves. However, this is contradicting for those who received the fund from scholarship or through the fellowship program. They found that they don't encounter with financial difficulty as they can spend the money from fund/ fellowship allowance for their education purposes and daily expenses.

\section{Excerpt 4 (Informant 2)}

"Aaa. I am always worried in spending my money. Because it is not enough for me sometimes. I'm self-sponsored. I don't want to upset my parents and make them worry about me; they always ask about money, but I always say I'm okay with it. Most of the time, I take my meal once a day and opt to walk more to class rather than using public transport. There are times a friend who has a car fetch me up. I have to sacrifice because I'm not born with silver spoon. It is so stressful for me. I don't know who I want to tell the story to. "

\section{Excerpt 5 (Informant 5)}

"For your information, I'm currently under a fellowship program in my university. So, I can use my fellowship allowance for my education and for my living spend. I don't have any worries to go anywhere for data collection or attending conferences as I can get subsidization from Malaysian government."

\section{Excerpt 6 (Informant 1)}

"In fact, I don't have much problem in regard to financial status. I've been spending most of my scholarship funding to buy everything that is needed for my learning here. At the same time, I'm not worry about my daily spends here as I found that Malaysia provides me with a low-cost living requirement. I'm so grateful to be here."

\section{Sub-Theme 2 (Financial Management)}

Financial management is very crucial skills that need to be mastered by foreign student. Failure to plan the expenses involved in life as a student will lead to the financial inadequacy, difficulty in concentrating to academic learning and further lead to increase level of stress.

\section{Excerpt 7 (Informant 3)}

"Yeaaa.. Frankly speaking, there is a financial problem because there is a lot of money need to be spent on. Ermm. It feels very stressful when thinking about money. I don't get scholarship. But I come from high-income family. I can't spend my money randomly. Need to manage it well. I have to prioritize my need. If not, it will compromise both my education and living here". 


\section{Psychological Stressor}

Psychological aspect is very important in order to ensure that each foreign student able to adjust themselves in the new environment in the host country. Failure to do the adjustment will leads to the psychological disturbances and further affect student's mental and physical health.

\section{Sub-Theme 1 (Loneliness)}

Several participants expressed their feelings of loneliness and separation, mainly in their first weeks after arriving in Malaysia. The loneliness was contributed by the fact that they are far from their family, feeling alienated being in the new environment and no established peer support.

\section{Excerpt 8 (Informant 5)}

"... Aaa... At first, it is so lonely because I felt that I'm too far with my family...I has no friends. I did everything on my own. Go to the class, eat alone. Need to adapt anyways. It is quite stressful for me. But when I started attending the class, I met a friend from Iran. So, from that time on, I started to have friends. I don't feel lonely anymore ... "

\section{Excerpt 9 (Informant 4)}

"When I arrived in Malaysia, I felt alone. Helpless. Everything is so strange and new for me. It's a bit hard on me to adjust into this environment. It makes me stress."

\section{Sub-Theme 2 (Homesickness)}

In fighting with homesickness, each of the participants may have their own way to go through it. It is very important for them to know on how to channel out their homesickness. Some of them will make a frequent call or messaging through phone call, WhatsApp, Facebook or through a lot of other social media. Meanwhile, some of them enjoy themselves with entertainment related to their country.

\section{Excerpt 10 (Informant 3)}

“... Yeah.. I missed my home so much .I always feel that I want to go back to my hometown. I missed my family so much. I frequently make a phone call with my parents. Sometimes just contact them through WhatsApp or using my Facebook. If given a chance, I always want to go back frequently."

\section{Excerpt 11(Informant 5)}

"I always feel homesick. Sometimes if I really missed my family and my country, I'll watch Turkish drama and listen to the song. I feel okay then."

\section{Language Stressor}

Language mastery is a must for every foreign student. This includes language proficiency in both Malay and English language for them to survive throughout their academic years.

\section{Sub-Theme 1 (Language and Communication Barrier)}

Participants face difficulties not only in the classroom but also in their social life in view of their incompetency in Malay language. For example, they have to communicate in Malay language while doing their field work or trip and speak with the locals for their daily living 
deals. It causes uneasiness for them because some of the local citizen also cannot communicate well in English. Participants also stated that the communication patterns are very different, so they have to deal with some awkwardness during their social interaction. This leads to communication barrier.

Excerpt 12 (Informant 1)

"I confessed it's very difficult for me to master the Malay language. I really need a long time to speak in the Malay. Very difficult because most of the participants in my research involves Malays. Sometimes had to ask help from friends to become a translator. I also found that the way I communicate with them is also different."

\section{Excerpt 13 (Informant 4)}

"It is so hard for me when time needs me to speak in Malay especially when I want to buy food from the stall or even to get a taxi."

\section{Sub-Theme 2 (Lack of confidence in verbal skills)}

In view of participants' proficiency in Malay language is low, they experienced a lack of confidence in verbal skills. A lot of time, they just keep quiet and avoid from having conversation as they worried people will not understand with their conversation.

\section{Excerpt 14 (Informant 2)}

“... It's hard for him to talk at first. I'm not confident at all to speak Malay. I'll keep silence most of the time, not much to say. Social life is a bit less. I am worried people will not understand me. But over time, I think my Malay language better."

\section{Sociocultural Stressor}

Participants are coming from variety social cultures group, which differed from Malay sociocultural. Each of the participants have a different type of beliefs and value systems. When they are coming into a new culture, they need to face and adapt with a lot of different aspects in daily living includes interpersonal relationship patterns, value systems, communication method until it comes into food and normal daily life. Because of the differences, it sometimes led to misunderstanding and unsatisfaction in foreign students.

\section{Sub-Theme 1 (Cross-cultural friendships)}

In this study, participants found that there is difficulty in establishing a cross-cultural friendship with Malay students. Some of them feel that Malay students are so warmth, welcoming, friendly and helpful which make them easier to approach them and establish a relationship.

\section{Excerpt 15 (Informant 4)}

"I felt quite stressful to be here. I have no friends. especially from Malaysian students. They ignored me. They are not friendly."

\section{Excerpt 16 (Informant 5)}

"I have studied in another country before. I find the character of local students there is very different from Malaysia. I think Malaysian students are more friendly and like to help. They are so welcoming. I feel very happy to be in Malaysia. I get a lot of friends here". 


\section{Sub-Theme 2 (Food incompatibilities)}

The food choice also one of the challenges or stressors that most of the participants encountered. They found out that most of the food here are spicy and hot. Most of them found that they are not compatibles with the food. They need to cook by themselves. This condition further creates stress situation as most of the groceries are difficult to find in Malaysia and they need to spend their time for cooking.

\section{Excerpt 17 (Informant 3)}

"I can say all the food here is very spicy. I can't stand with it. Sometimes, I had stomach pain after eating because I'm not used to such food."

\section{Excerpt 18 (Informant 4)}

"For me, food is very important for students. If I don't eat, I cannot focus on my study. Most of the food here is spicy. That's why I prefer to cook. It's just that cooking ingredients are hard to find in Malaysia. I have to bring them from my country".

\section{Discussion}

This study revealed that there are a lot of stressors involved in self-adjustment among foreign students who pursuing their study in Malaysia. Analysis of the data resulted in five major themes which explained the different sources of stressor experienced by foreign student in adjusting themselves in Malaysia which include academic, financial, psychological, language and sociocultural stressor. The involved stressors are significantly affect their ability to make a good adjustment in the context of academic performance and living experiences in Malaysia.

In term of academic stressor, most of the participants revealed that teaching and learning approaches with English language and experiences with student support services are among the elements which contribute to their stress. Several students experienced difficulty in their teaching and learning in view of low proficiency in English language. This finding was consistent with previous study conducted by Ahrari et al (2019). Related to this issue, there are a lot of other previous studies reported that most of foreign students have insufficient English proficiency (Constantine et al., 2004; Hwang \& Tin, 2008). In these studies, the lack of English proficiency causing most of the participant involved to have difficulty in understanding class content, participating in classroom activities and communicating effectively with lecturers and other students. Besides that, they also have to spend extra time in accomplishing readings and homework assignments. This finding is supported by study conducted by Jeiru (2016) which explained the implication of English incompetence among foreign students in their teaching and learning process.

The study also revealed that majority of the participants had a bad experience with student support services. They did not feel comfortable seeking help from their lecturer and still unsure about the resources to seek for help whenever they are facing any problem. Similar finding was recorded in study done by Jeiru (2016) where perceived support from school was the only significant predictor of acculturative stress among foreign students. The study indicated that support service from school is very important to foreign students in their acculturation process where it can lower the stress levels and help in student's selfadjustment. It does not merely refer to tangible support such as a culturally friendly 
environment and facilities, but also moral support from people whom foreign students interact with, such as classmates, faculty, and staff members (Jeiru, 2016). Hsiao-ping et al (2015) further mentioned in detail the services needed by foreign students include student associations, writing center, counseling center, recreation, and various student organizations which enable them to have some space to release stress, to find a support group, and to gain strategies to deal with different problems.

From the perspective of financial stressor, the scholarship endorsement and financial management are the main stressors which interfere with student's adjustment. Most of them are supporting their educational expenses by themselves and few of them are financially supported by their own government funding or through university fellowship program. These finding was in line with Khawaja and Dempsey's study (2008) where in this study it was found that two thirds of the foreign students in Australia received financial support through their parents. In other study done by Ye \& Juni (2018), it was stated that failure to get scholarship endorsement will cause financial constraints and further lead to increase stress level.

In contrary, this situation is not happening in students who received scholarship or under fellowship scheme of the involved university. As what was found in study done by Jasvir (2018) revealed that foreign student in the research university where the study being conducted found that they don't have much problem with financial aspect as the Postgraduate Student Office offers a range of financial assistance, such as research grants, graduate assistant (GA) positions, fellowships and subsidies for foreign students to attend conferences. These allowed students to focus on their studies and research work without worrying about their financial status. In fact, a good financial management is vital to ensure the survival in living of the foreign students in Malaysia. Malaklolunthu \& Selan (2011) stated that foreign students in Malaysia have acknowledged that they have minimal issues with finance in view of the low cost of living in Malaysia.

Loneliness and homesickness are the psychological stressors pictured by many of the participants in this study. Desa, Yusooff and Kadir (2012); Ye \& Juni (2018); Ahrari et al (2019) revealed that homesickness, loneliness, safety and peacefulness, as well as anxiety are among the elements involved in psychological stress which further led to poor adjustment of foreign student in the host country. The finding was also supported by other study done in Western country (Mesidor \& Sly, 2016; Yeoh \& Terry, 2013; Lama, 2013) which revealed similar findings. This aspect cannot be taken lightly as it will affect the overall psychological wellbeing of the students and further disturbed student's mental health and academic performance. As what was mentioned in Tochkov's et al (2010) study of Asian-Indian students in the United States which revealed that homesickness and loneliness are negatively influenced academic performance.

Majority of the participants involved in this study have a poor competency in Malay language. This issue led to the lack of confidence in verbal skills in foreign students and emerging communication barrier. As discussed earlier on in this section, most of the participants have a low proficiency in English which further lead to the acculturative stress level. The poor competency in Malay indeed exacerbated these issues. Even though English language is a teaching language in university involved in this study, the Malay proficiency in particular is vital in order to communicate with locals during field work or trip and daily living 
deals. Similar finding was found in participants involved in study done by Ye \& Juni (2018). This condition is further worsened by the lack of confidence in verbal skills by foreign students. Hsiao-ping et al (2015) mentioned that language barriers could affect students' academic learning, participation in different events, and cultural understanding in host countries. The finding was also supported by study done by Desa et al (2012) which revealed that students' degree of proficiency in the host country language may cause them difficulty whenever they need to manage unexpected issues happened.

In addition, sociocultural aspect also one of the contributing causes of stress for foreign students. In this study, participants had a mixed experience in establishing crosscultural relationship with Malaysian student. Half of them felt that Malaysian students are friendly, helpful and warm in their friendship with them. Meanwhile, half of them found that it is difficult to create a cross-cultural relationship with Malaysian students. This finding is in line with study done by Ahrari et al (2019) which pictured similar findings. This phenomenon can be explained by the fact that Malaysian cultural values of shyness, constrained display of emotions, respect for others, and a collectivistic standard of living which might be incorrectly perceived as unfriendly by foreign students and further lead to communication challenge (Mahmud et al., 2010). Besides that, food incompatibilities are also stressors which disturb in student's adjustment. As what was found in other previous study (Vilela et al., 2014; Ye \& Juni, 2018), living conditions attributed by climate, eating habits, housing condition, the way of transportation and other factors can influence acculturative stress among foreign students in host country.

\section{Conclusion}

In fact, this research compliment finding from previous quantitative-based studies regarding understanding stress among foreign students and their implication in student's selfadjustment. This study able to capture student's pure opinions and emotions regarding their experiences through exploratory approach in qualitative study. The findings indicated that foreign students often encountered with several stressors throughout their academic years in Malaysia. On the other hand, the emerging stressor indeed becoming challenges to them which motivate foreign students to develop strategies to adjust themselves in Malaysia.

This study reminds that the adjustment and adaption take time and effort. It needs a lot of support from different bodies involved with foreign student's management and at the same time it needs a lot of consideration from multiple aspects of academic and student's live-in university. The findings not only increase our insight about the stress aspects in foreign student self-adjustment but also provide information for developing effective university policies and teaching practices as well as counselling strategies to enhance the wellbeing of the foreign students. In accordance with this study finding, an intervention can be developed where students' stories can be used to increase the successful adaption for subsequent foreign students.

\section{Corresponding Author}

Abdul Rashid bin Abdul Aziz

Faculty of Leadership and Management Universiti Sains Islam Malaysia, 71800, Bandar Baru

Nilai, Negeri Sembilan, Malaysia

Email: rashid@usim.edu.my 


\section{References}

Ahrari, S., Krauss, S. E., Suandi, T., Abdullah, H., Sahimi, A. H. A., Olutokunbo, A. S., \& Dahalan, D. (2019). A stranger in a strange land: Experiences of adjustment among foreign postgraduate students in Malaysia. Issues in Educational Research, 29(3), 611-632.

Morrow, A. R. N. (2019). Stress and The Dying Process. Retrieved on August 21, 2020 Retrieved from https://www.verywellhealth.com/defining-stress-1132264

Annuar, S. S. (2017). Malaysia terima 200,000 pelajar antarabangsa menjelang 2020. Berita Harian. Retrieved from https://www.bharian.com.my/berita/nasional/2017/03/262466/msia-terima-200000pelajar-antarabangsa-menjelang-2020.

Aris, M. (2014). Pengurusan Stres: Memahami Stress dan Teknik Mengawal Stres. Selangor: Penerbitan Multimedia.

Cheng, M. Y., Mahmood, A., \& Yeap, P. F. (2013). Malaysia as a regional education hub: A demand-side analysis. Journal of Higher Education Policy and Management, 35(5), $523-$ 536.

Choudaha, R., Chang, L. (2012). Trends in foreign student mobility. Research report. World education services.

Constantine, M. G., Okazaki, S., \& Utsey, S. O. (2004). Self-concealment social self-efficacy, acculturative stress, and depression in African, Asian, and Latin American foreign college students. American Journal of Orthopsychiatry, 74, 230-241.

De Araujo, A. A. (2011). Adjustment issues of foreign students enrolled in American colleges and universities: A review of the literature. Higher Education Studies, 1, 2-8.

Deitchman, J. (2014). Factors influencing the adjustment of foreign students enrolled at public higher education institutions in New York state: An examination of between group differences [Doctoral thesis], State University of New York at Albany.

Desa, A., Yusooff, F., \& Kadir, N. B. Y. A. (2012). Acculturative stress among foreign postgraduate students at UKM. Procedia-Social and Behavioral Sciences, 59, 364-369. Diagnostic and Statistical Manual of Mental Disorder V, DSM-V. (2018). American Psychiatric Association.

Gebhard, J. G. (2012). Foreign Student's Adjustment Problem and Behaviors. Journal of Foreign Students, 2(2), 184-193.

Hwang, W. C., \& Ting, J. Y. (2008). Disaggregating the effects of acculturation and acculturative stress on the mental health of Asian students. Cultural Diversity and Ethnic Minority Psychology, 14(2), 147-154.

Singh, J. K. N. (2018). What are the factors that contribute to postgraduate foreign students' academic success? A Malaysian qualitative study, Higher Education Research \& Development, 37(5), 1035-1049.

Jean, K. M., \& Kaye, F. S. (2016). Factor that contributes to the adjustment of foreign students. Journal of Foreign Students, 6(1), 262-282.

Jeiru Bai. (2016). Perceived Support as a Predictor of Acculturative Stress Among Foreign Students in the United States. Journal of Foreign Students, 6(1), 93-106.

Khawaja, N. G., \& Dempsey, J. (2008). A comparison of foreign and domestic tertiary students in Australia. Australian Journal of Guidance and Counselling, 18(1), 30-46.

Lama, S. (2013). Attitudes and perceptions of mental disorders among individuals from Nepal [Masters Thesis], St. Catherine University, St. Paul, MN.

Lam, J. M. S., Tong, D. Y. K., \& Ariffin, A. A. M. (2017). Exploring perceived risk and risk reductionstrategies in the pursuit of higher education abroad: A case of foreign 
students in Malaysia. Journal of Studies in Foreign Education, 21(2), 83-104.

Mahmud, Z., Amat, S., Rahman, S., \& Ishak, N. M. (2010). Challenges for foreign students in Malaysia: Culture, climate and care. Procedia - Social and Behavioral Sciences, 7, 289293.

Malaklolunthu, S., \& Selan, P. S. (2011). Adjustment problems among foreign students in Malaysian private higher education institutions. Procedia - Social and Behavioral Sciences, 15, 833-837.

Malaysia Education Blueprint 2015-2025 (Higher Education). (2015). Ministry of Education. Retrieved from 1st October 2020 from https://www.mohe.gov.my/en/pppm-pt

Mesidor, J. K., \& Sly, K. F. (2016). Factors that contribute to the adjustment of foreign students. Journal of Foreign Students, 6(1), 262-282.

Ministry of Education Malaysia. (2018). Higher Education Statistics. Kuala Lumpur, Malaysia.

Mittal, M., \& Wieling, E. (2006). Training experiences of foreign doctoral students in marriage. Journal of Marital and Family Therapy, 32(3), 369-383.

Mustafa, M. Z., Suradin, A., Muhamad, S. S, Madar, A. R., \& Razzaq, A. R. (2009). Stres dalam Kalangan Pelajar Wanita Program Sarjana Muda Kejuruteraan di Universiti Tun Hussein Onn Malaysia. Proceedings of the Foreign Conference On Teaching and Learning in Higher Education (Ictlhe), 23 - 25 November 2009.

MOHE. (2011). Perangkaan pengajian tinggi Malaysia. Kuala Lumpur, Malaysia. Ministry of Higher Education. Retrieved from http://mohe.gov.my/muatturun/awam/statistik/2011/89-perangkaan-pengajian-tinggi-malaysia-2011

Mori, S. (2000). Addressing the mental health concerns of foreign students. Journal of Counseling and Development, 78,137-144.

Nilsson, J. E., Butler, J., Shouse, S., \& Joshi, C. (2008). The relationships among perfectionism, acculturation, and stress in Asian foreign students. Journal of College Counseling, 11, 147-151.

Othman, K \& Sipon, S. (2012). Researching solution based on Islamic views and practice in managing financial and work place stress. Foreign Journal of Academic Research in Business and Social Sciences, 2(8), 239-252.

Poyrazli, S., \& Grahame, K. M. (2007). Barriers to adjustment: Needs of foreign students within a semi-urban campus community. Journal of Instructional Psychology, 34(1), 2836.

Russell, J., Rosenthal, D., \& Thomson, G. (2010). The foreign student experience: three styles of adaptation, Higher Education, 60(2), 235-249.

Safary, W. M., \& Nadine A. J. (2013). Foreign Students' Isolation in the Philippines: Causes, Effects and Coping Strategies. Development Education Journal of Multidisciplinary. 2(1).

Salleh, S. M., \& Hussin, S. K. (2017). Tekanan Akulturasi Pelajar Malaysia di Luar Negara. qMalaysian Journal of Communication, 33(1), 340-355.

Sarafino, E. P. (2012). Health Psychology: Biopsychosocial Interactions. 7th Ed. Asia: Wiley. Self-adjustment Definition by Merriam-Webster.com Dictionary, Merriam-Webster. Retrieved from https://www.merriam-webster.com/dictionary/self-adjustment.

Suseela, M., \& Poovaikarasi, S. S. (2011). Adjustment problems among foreign students in Malaysian private higher education institutions. Procedia Social and Behavioral Sciences, 15, 833-837.

Tochkov, K., Levine, L., \& Sanaka, A. (2010). Variation in the prediction of cross-cultural adjustment by Asian-Indian students in the United States. College Student Journal, 44(3), 677-689. 
Trice, A. G. (2004). Mixing it up: Foreign graduate students' social interactions with American students. Journal of College Student Development, 45(6), 671-687.

Vilela, S., Santos, S., Padrao, P., \& Caraher, M. (2014). Length of migration and eating habits of Portuguese university students living in London, United Kingdom. Ecology of food and nutrition, 53(4), 419-435.

Wu, H., Garza, E., \& Guzman, N. (2015). Foreign Student's Challenge and Adjustment to College. Education Research Foreign. 2015, 202753.

Ye, H. D., \& Juni, M. H. (2018). Predictors of Acculturative Stress Among Foreign Postgraduate Students in Malaysia Public University. Foreign Journal of Public Health and Clinical Sciences, 5(3). 155-172.

Yeoh, J. S. W., \& Terry, D. R. (2013). Foreign research students' experiences in academic success. Universal Journal of Educational Research, 1(3), 275-280. 